\title{
Environmental diagnosis of water source in a Brazilian Cerrado watershed
}

\author{
Fernanda Laurinda Valadares Ferreira ${ }^{1 *}$, Francielle de Cássia Coelho Vieira ${ }^{2}$, Izabelle de Paula Sousa ${ }^{3}$, Flávio \\ Pimenta de Figueiredo ${ }^{4}$, Leidivan Almeida Frazão ${ }^{5}$
}

DOI: https://doi.org/10.35699/2447-6218.2020.20739

\begin{abstract}
A lack of planning characterize the most demographic occupation process in Brazil, occurring in a disorderly manner and with inappropriate occupations, resulting in damage to natural resources. This process is recurrent in the Cerrado Biome, currently the agricultural frontier of the country. Thus, the objective of this work was to identify anthropic activities and classify the conservation status in the headsprings (water sources) and surroundings areas of a watershed inserted in the Cerrado biome, besides proposing measures to prevent and control the different degradation processes. From February to July 2016, visits were made to 37 headsprings and their surroundings, located in the watershed of Santa Fé de Minas River. Impacts of anthropic actions are identified directly or indirectly, classifying the areas according to the state of conservation: preserved, anthropized and degraded. All visited places presented some type of negative interference from human activities. The most frequent activities were unpaved roads, monoculture of eucalyptus and cattle farming. According to the classification, only $6 \%$ of the areas are on preserved condition, while $70 \%$ are anthropized and $24 \%$ degraded. The main types of found degradation were erosions in different stages, compaction and silting. In addition, no conservationist practices are present in the areas. Therefore, to reduce or prevent future degradation in the watershed, it proposed some mitigating actions, such as the isolation of headsprings and their surroundings, adaptation of roads and eucalyptus plantation areas, and maintenance of preservation areas.
\end{abstract}

Key words: anthropic activities. degradation conditions. mitigating actions.

\section{Diagnóstico ambiental de nascentes em uma bacia hidrográfica do Cerrado brasileiro}

\section{Resumo}

O processo de ocupação demográfica no Brasil em sua maioria é caracterizado pela falta de planejamento, ocorrendo de forma desordenada e com ocupações inadequadas, resultando em danos aos recursos naturais. Este processo é recorrente no Bioma Cerrado, atualmente a fronteira agrícola do país. Assim, objetivou-se com este trabalho, identificar as atividades antrópicas e classificar o estado de conservação nas áreas de nascentes e entorno de uma bacia hidrográfica inserida no bioma Cerrado, e propor medidas para prevenir e controlar os diferentes processos de degradações. No período de fevereiro a julho de 2016, foram realizadas visitas em 37 nascentes e seus entornos, localizadas na bacia do rio Santa Fé de Minas. Foram identificados impactos das ações antrópicas de forma direta ou indireta, classificando as áreas de acordo com o estado de conservação: preservada, antropizada e degradada. Todos os locais visitados possuíam algum tipo de interferência negativa proveniente de atividades antrópicas. As atividades de maior recorrência foram estradas não pavimentadas, monocultivo de eucalipto e bovinocultura. De acordo com a

${ }^{1}$ Universidade Federal de Viçosa, Departamento de Engenharia Agrícola. Viçosa, MG.Brasil.

https://orcid.org/0000-0003-3206-8467

${ }^{2}$ Universidade Federal de Minas Gerais, Instituto de Ciências Agrárias. Montes Claros, MG. Brasil.

https://orcid.org/0000-0003-3656-1793

${ }^{3}$ Universidade Federal de Viçosa, Departamento de Engenharia Agrícola.Viçosa, MG. Brasil.

https://orcid.org/0000-0002-5176-4612

${ }^{4}$ Universidade Federal de Minas Gerais, Instituto de Ciências Agrárias.Montes Claros, MG. Brasil. https://orcid.org/0000-0002-7147-7821

${ }^{5}$ Universidade Federal de Minas Gerais, Instituto de Ciências Agrárias. Montes Claros, MG. Brasil. https://orcid.org/0000-0001-6848-9007

*Autora para correspondência: fernanda_laurinda@yahoo.com.br

Recebido para publicação em 19 de maio de 2020. Aceito para publicação em 13 de setembro de 2020. e-ISSN: 2447-6218 / ISSN: 2447-6218. Atribuição CC BY. 
classificação, apenas 6\% das áreas foram classificadas como preservadas, enquanto $70 \%$ estavam antropizadas e $24 \%$ degradadas. Os principais tipos de degradações encontrados foram erosões em diferentes estágios, compactação e assoreamento. Além disso, foi constatado que nenhuma prática conservacionista é adotada nas áreas. Portanto, para reduzir ou evitar futuras degradações na bacia foram propostas medidas mitigadoras, como o isolamento das nascentes e seu entorno, adequação de estradas e áreas de plantio de eucalipto, e manutenção das áreas de preservação.

Palavras-chave: atividades antrópicas. condições de degradação. ações mitigadoras.

\section{Introduction}

In the last decades, the demand for natural resources has been increasing in a worrying way, due to the demand being greater than the capacity to replace the resources. Population growth, coupled with the growth of industries and agriculture, provides socio-environmental damage, when they occur without planning (Ferreira et al., 2015; Mota et al., 2016; Silva et al., 2016).

Environmental or urban population growth generally occurs in a disorderly manner and without planning, reflecting in occupations of inadequate areas (Ferreira et al., 2015). In the Brazilian territory, this occupation process occurs sharply, associated with the lack of management, destruction of riparian forests and areas of permanent preservation (APP's), resulting in the deterioration of natural resources (Garcia et al., 2015; Mendes et al., 2016).

According to Garcia et al. (2015), for the study of watersheds, it is necessary to analyze APP's. The natural characteristics of Brazilian watersheds change due to anthropic activities, especially in micro-watersheds (small watershed), where streams show signs of deterioration (Ferreira et al., 2015). Inappropriate use and occupation of the areas on hillsides and river margins generally cause environmental impacts of high magnitude in watersheds, causing socio-environmental problems (Albuquerque et al., 2017).

The knowledge linked to the preservation of headsprings (water sources) in the watershed, is extremely important for the maintenance of watercourses. The headsprings concentrate on slopes, in the depressions of land, or at the base level of the local watercourse (Galatto et al., 2011). They are classified according to their flow as perennial (they manifest throughout the year, but with flow variations), temporary (manifest during the rainy season, and disappear in the dry season) and ephemeral (temporary, only when rain occurs) (Palivoda and Povaluk, 2015).

According to CONAMA Resolution nº 303/2002, the headsprings are natural water outcrops of groundwater, which are preservation areas. The vegetation protection in headsprings is extremely important, due to their performance, as an obstacle for surface runoff, favoring the infiltration of water in the soil profile and reducing the risks of erosion (Silva et al., 2018). The
Brazilian Forest Code - Law no 12.651/12 (Brazil, 2012) considers APP's as "the areas around the headsprings and perennial water eyes, whatever their topographic situation, within a minimum radius of 50 (fifty) meters". Thus, the headsprings and their surrounding vegetation are protected due to their fragility and usefulness (Silva Junior et al., 2015).

Occupation that occurs in a disorderly manner and in areas of environmental protection such as the top of hills, slopes and margins of water courses has become a problem, as it can cause the destruction of legal reserve areas, APP's, among others (Mota et al., 2016). The disobedience of the legislation in the areas of APP's together with inadequate land use and coverage, poses risks to the quality and quantity of water resources, since it alters the river dynamics and the runoff (Garcia et al., 2015; Moura et al., 2017).

For recovery and preservation of these places, it is necessary to carry out an environmental diagnosis (Mota et al., 2016), which consists of interpreting the current situation in which the environment of a given area is found, thus seeking to know its components (Silva et al., 2018). According to Garcia et al. (2015), the environmental diagnosis of land use and coverage with the use of geotechnologies allows an integrated analysis of the environment based on the obtained information.

The Cerrado biome is the second largest in Brazil, occupying an area of approximately $24 \%$, and it is considered the richest savanna in the world (Aguiar et al., 2016), with a high endemism index (Calaça et al., 2018). Due to its extension, the Cerrado presents transition zones with almost all other national biomes, being responsible for the formation of the main Brazilian rivers (Aguiar et al., 2016). This biome has been considered, since the 1970s, the main agricultural frontier area in the country, being responsible for about $70 \%$ of national food production (Silva et al., 2015a).

Changes in land use and coverage from the advancement of anthropic actions, with the suppression of native vegetation areas, can cause changes in hydrological regimes in river watersheds (Ferreira et al., 2020). Therefore, the objective of this work was to identify anthropic activities and classify the conservation status in the areas of headsprings and their surroundings, located at 
a watershed inserted in the Cerrado Biome, and propose actions to prevent and control the different degradation processes.

\section{Material e methods}

The environmental diagnosis was carried out in the watershed of the Santa Fé de Minas River, in Santa
Fé de Minas County, located in the Pirapora micro-region and meso-region of Northern Minas Gerais. The watershed under study drains an area of approximately 1,470 $\mathrm{km}^{2}$, which is a sub-watershed of the Paracatu river and, according to the division of the watershed committees, belongs to the watershed of São Francisco river (Figure 1), framing the SF7 committee - Paracatu (IGAM, 2006).

Figure 1 - Watershed of the Santa Fé de Minas River, Minas Gerais, Brazil

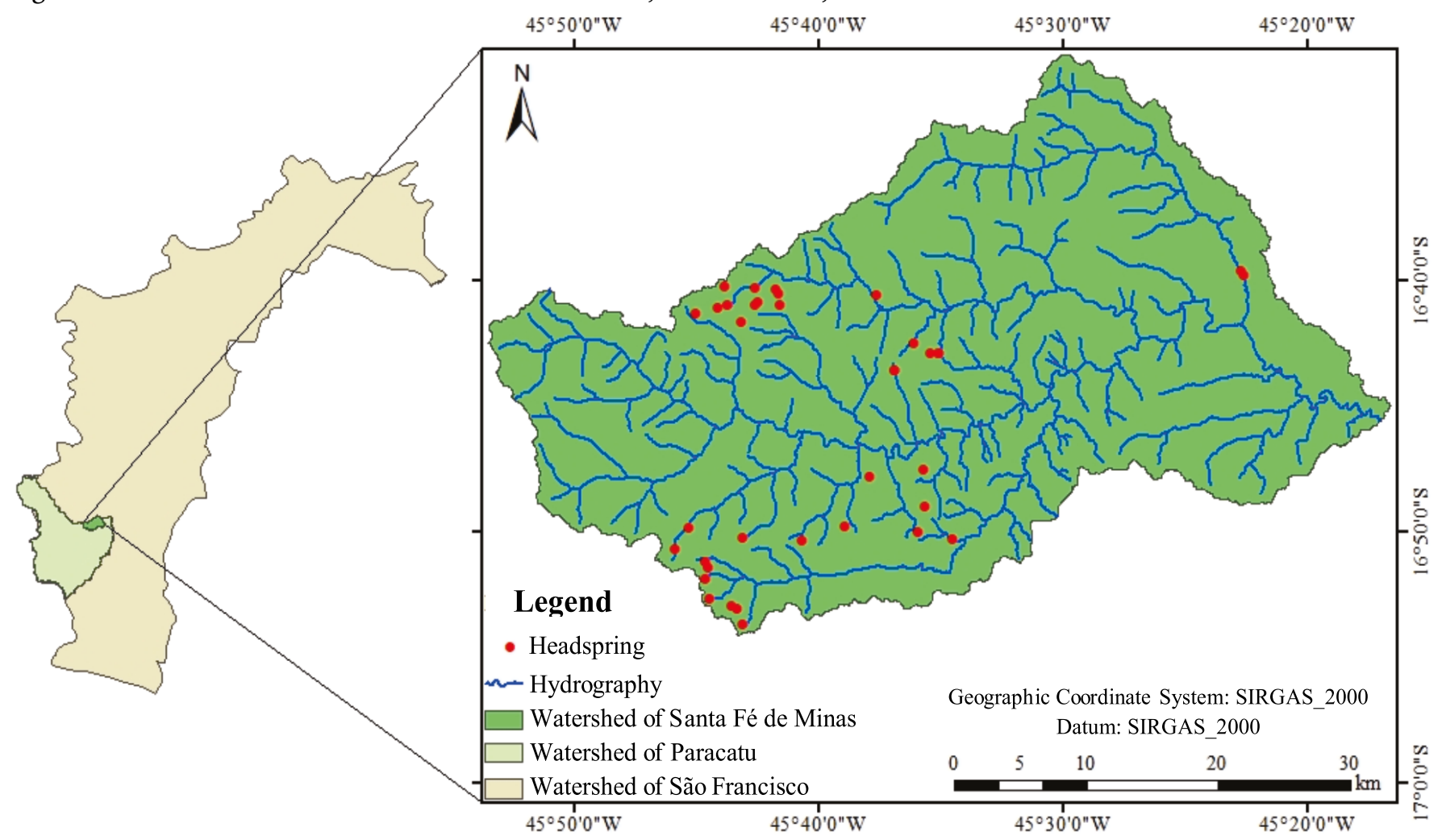

The predominant biome characteristic of the region under study is the Cerrado. According to IBGE (2010), the county Santa Fé de Minas has an area equivalent to $2,917.45 \mathrm{~km}^{2}$, with an altitude of about $500 \mathrm{~m}$, a population of approximately 4,000 inhabitants, with agriculture being the main economic activity.

According to the climatic classification of Köppen (Köppen, 1936), Aw is the predominant climate in the watershed region, a tropical climate with dry winter, rainy season in summer, between the months of November and April, and dry season in winter, from May to October, being July the driest month.

For collection and analysis of data related to the headsprings environmental diagnosis, field visits were carried out between the months of February and July 2016, which consisted of identifying the impacts that occurred on the analyzed area and the actions interaction that impacted the place (site) directly and indirectly.

During expeditions through the watershed, evaluations were carried out in 37 headsprings and in their surroundings, which were georeferenced using a GPS device (Global Positioning System) (Figure 1). The identification of the headsprings and the respective coordinates are shown in Table 1.

In all the visited places (sites), annotations were made about the conservation current state of the headsprings and their surrounding areas, in addition to photographic records for eventual consultations and proof of the anthropic changes incidence. The headsprings were classified as proposed by Pinto (2003), and adaptations were made. The classification took place as follows:

a) Preserved: headsprings with native vegetation and without human intervention evidence;

b) Anthropized: native vegetation in the headsprings and their surroundings, with anthropic intervention; and

c) Degraded: areas with little or no native vegetation, highly compacted soil or with erosion in an advanced state, and silted watercourses. 
Ferreira, F. L. V. et al.

Table 1 - Identification and location of the visited headsprings (water sources) in the watershed of Santa Fé de Minas river, Minas Gerais, Brazil

\begin{tabular}{|c|c|c|c|}
\hline \multirow{2}{*}{$\frac{\text { Headspring }}{1}$} & \multirow{2}{*}{$\begin{array}{l}\text { Popular Names } \\
\text { Córrego do Frade }\end{array}$} & \multicolumn{2}{|c|}{ Geographic Coordinates } \\
\hline & & S $16^{\circ} 50^{\prime} 15,5^{\prime \prime}$ & $\mathrm{W} 45^{\circ} 34^{\prime} 31,1^{\prime \prime}$ \\
\hline 2 & Cabeceira do Areal & S $16^{\circ} 48^{\prime} 56,8^{\prime \prime}$ & 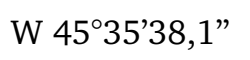 \\
\hline 3 & Nascente da Lagartixa & S 16²'32,7' & W 453’3, \\
\hline 4 & Vereda Comprida & S $16^{\circ} 50^{\prime} 12,1^{\prime \prime}$ & W 454’'5,9” \\
\hline 5 & Nascente do Buraco & S $16^{\circ} 47^{\prime} 29,2^{\prime \prime}$ & W 453' $35^{\prime} 41,5^{\prime \prime}$ \\
\hline 6 & Nascente do Mandu & S $16^{\circ} 47^{\prime} 44^{\prime \prime}$ & W 453'ㄴ, $54 ”$ \\
\hline 7 & Nascente do Riachão & S $16^{\circ} 50^{\prime} 17,2^{\prime \prime}$ & W 4540’41,7” \\
\hline 8 & Nascente Ponte Pedra & S $16^{\circ} 49^{\prime} 43,2^{\prime \prime}$ & W 453'ㄷㄴ, \\
\hline 9 & Nascente Riachão das Pedra & S $16^{\circ} 49^{\prime} 59,6^{\prime \prime}$ & W 453'ㄷㄴ, \\
\hline 10 & Nascente Cabeceira 3 da Extrema & S $16^{\circ} 51^{\prime} 21,1^{\prime \prime}$ & W 454' $30,9^{\prime \prime}$ \\
\hline 11 & Nascente Bacia do Extrema & S $16^{\circ} 51^{\prime} 7,1^{\prime \prime}$ & 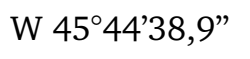 \\
\hline 12 & Vereda Grande & S $16^{\circ} 49^{\prime} 46,7^{\prime \prime}$ & W 454' $19,8^{\prime \prime}$ \\
\hline 13 & Cabeceira da Serrinha & S $16^{\circ} 52^{\prime} 36,3^{\prime \prime}$ & W 454'ㄹ, 28, \\
\hline 14 & Cabeceira da Vereda Grande & S $16^{\circ} 50^{\prime} 39,5^{\prime \prime}$ & W 454'ㄱㄱ, \\
\hline 15 & Cabeceira de Marotim & S $16^{\circ} 52^{\prime} 54,1^{\prime \prime}$ & W 454’ $33,3^{\prime \prime}$ \\
\hline 16 & Cabeceira da Extrema & S $16^{\circ} 53^{\prime} 1,8^{\prime \prime}$ & W 454'ㅇ' \\
\hline 17 & Galho da Passagem da Clauzi & S $16^{\circ} 53^{\prime} 39,3^{\prime \prime}$ & W 454’ $5,8^{\prime \prime}$ \\
\hline 18 & Galho da Serrinha & S $16^{\circ} 51^{\prime} 51,8^{\prime \prime}$ & 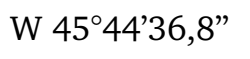 \\
\hline 19 & Nascente do Córrego das Lages & S $16^{\circ} 42^{\prime} 50,7^{\prime \prime}$ & W $45^{\circ} 35^{\prime} 3,4^{\prime \prime}$ \\
\hline 20 & Nascente das Águas Vertentes Lavado & S $16^{\circ} 42^{\prime} 50,7^{\prime \prime}$ & W $45^{\circ} 35^{\prime} 3,4^{\prime \prime}$ \\
\hline 21 & Nascente da Fuga & S $16^{\circ} 42^{\prime} 51,2^{\prime \prime}$ & $\mathrm{W} 45^{\circ} 35^{\prime} 26,2^{\prime \prime}$ \\
\hline 22 & Vereda Brejo do Arroz & S $16^{\circ} 43^{\prime} 32,3^{\prime \prime}$ & $\mathrm{W} 45^{\circ} 36^{\prime} 53,2^{\prime \prime}$ \\
\hline 23 & Nascente do Cedro & S $16^{\circ} 42^{\prime} 27,7^{\prime \prime}$ & $\mathrm{W} 45^{\circ} 36^{\prime} 6,6^{\prime \prime}$ \\
\hline 24 & Nascente do Caju & S $16^{\circ} 43^{\prime} 32,3^{\prime \prime}$ & W $45^{\circ} 36^{\prime} 53,2^{\prime \prime}$ \\
\hline 25 & Nascente 1 da Vereda do Inferno & S $16^{\circ} 41^{\prime} 3,8^{\prime \prime}$ & W $45^{\circ} 44^{\prime} 7,2^{\prime \prime}$ \\
\hline 26 & Nascente 1 do Lavado & S $16^{\circ} 40^{\prime} 28,0^{\prime \prime}$ & W $45^{\circ} 41^{\prime} 38,2^{\prime \prime}$ \\
\hline 27 & Nascente 2 da vereda do inferno & S $16^{\circ} 41^{\prime} 35,2^{\prime \prime}$ & W $45^{\circ} 43^{\prime} 8^{\prime \prime}$ \\
\hline 28 & Nascente 2 do Lavado & S $16^{\circ} 40^{\prime} 16,7^{\prime \prime}$ & W $45^{\circ} 41^{\prime} 45,9^{\prime \prime}$ \\
\hline 29 & Nascente 3 do Lavado & S $16^{\circ} 40^{\prime} 48,1^{\prime \prime}$ & W $45^{\circ} 42^{\prime} 29,4^{\prime \prime}$ \\
\hline 30 & Nascente 4 do Lavado & S $16^{\circ} 40^{\prime} 54,4^{\prime \prime}$ & W 45 42'34,7' \\
\hline 31 & Nascente Cabeceira do São Gregório & S $16^{\circ} 40^{\prime} 54,4^{\prime \prime}$ & W $45^{\circ} 41^{\prime} 33,2^{\prime \prime}$ \\
\hline 32 & Nascente Meio do Lavado & S $16^{\circ} 40^{\prime} 13,4^{\prime \prime}$ & W $45^{\circ} 42^{\prime} 34,7^{\prime}$ \\
\hline 33 & Nascente Principal do Lavado & S $16^{\circ} 40^{\prime} 11,6^{\prime \prime}$ & W $45^{\circ} 43^{\prime} 50,4^{\prime \prime}$ \\
\hline 34 & Nascente Vereda do Inferno & S $16^{\circ} 41^{\prime} 15,1^{\prime \prime}$ & W 45 $45^{\prime} 1,7^{\prime \prime}$ \\
\hline 35 & Nascente do Lavado & S $16^{\circ} 40^{\prime} 54,8^{\prime \prime}$ & W $45^{\circ} 43^{\prime} 42,6^{\prime \prime}$ \\
\hline 36 & Nascente Brejo vereda & S $16^{\circ} 39^{\prime} 42,7^{\prime \prime}$ & $\mathrm{W} 45^{\circ} 22^{\prime} 35,3^{\prime \prime}$ \\
\hline 37 & Nascente do Mucambo & S $16^{\circ} 39^{\prime} 33,4^{\prime \prime}$ & W 45 22' 41,3" \\
\hline
\end{tabular}


Ferreira, F. L. V. et al.

The places classified as anthropized were distributed in groups defined by the authors, according to the scenarios observed in the on-site visit, indicating the anthropization degree, which varies according to the activities carried out in the surrounding areas (Table 2).

Table 2 - Anthropization degree according to anthropic activity existing in the headsprings (water sources) areas and their surroundings, visited in the watershed of the Santa Fé de Minas River, Minas Gerais, Brazil

\begin{tabular}{ll}
\hline Anthropization degree & Anthropization Activity \\
\hline \multirow{2}{*}{ Low } & Road with vegetation around \\
& Eucalyptus planted within APP's \\
& Road without vegetation and/or inserted in the APP's \\
& Eucalyptus planted within the headspring areas \\
Medium & Laminar erosion \\
& Presence of cattle \\
& Road without vegetation and with erosion beginning \\
& Eucalyptus planted towards the slope of the land (downhill) \\
High & Groove erosion \\
\hline
\end{tabular}

The classification of the water erosion types incident in the areas was carried out, being classified as laminar erosion, where a thin layer is removed from the soil top; or linear erosion, characterized by incisions in the soil, ranging from small grooves (furrow erosion) to the shape of gullies (Morais and Sales, 2017).
Basin on the field visiting and the conservation status diagnosis of the 37 headsprings and surrounding areas, all the evaluated sites have some kind of anthropic interference with negative impacts on the local ecosystem, especially water resources. Figure 2 shows some of the scenarios found in the headsprings and surrounding areas.

\section{Results and discussion}

Figure 2 - Some of the scenarios observed in the headsprings (water sources) areas and their surroundings in the watershed of the Santa Fé de Minas River, Minas Gerais, Brazil
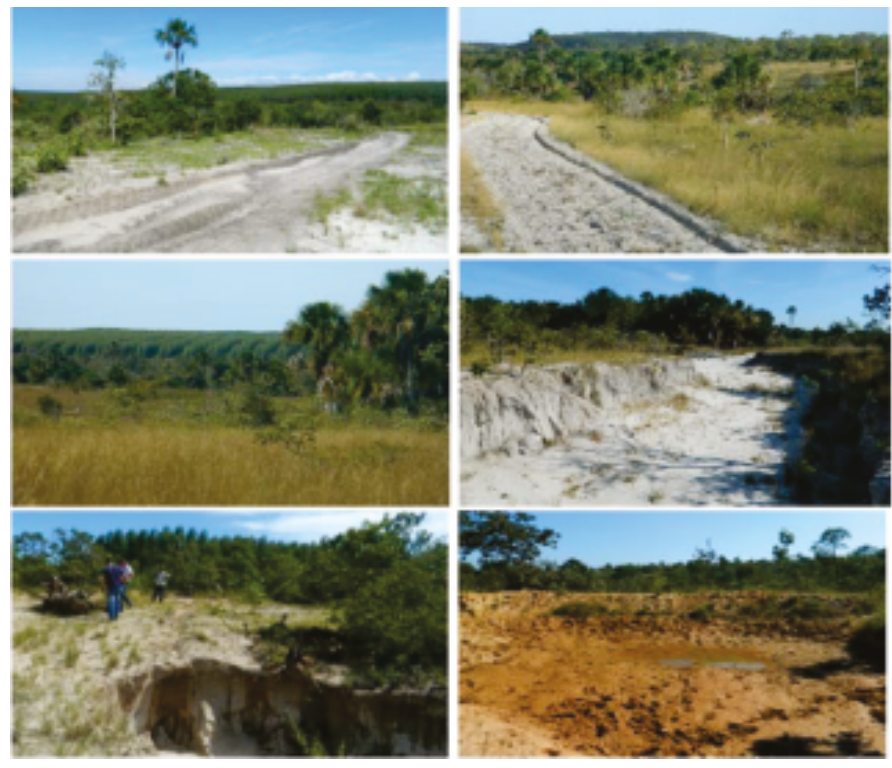

The anthropic intervention observed in all visits was the presence of unpaved and unplanned roads, which were used to move around the properties or access the eucalyptus monoculture plots. In all the places visited, roads are in or near the APP's, some of which pass within the headsprings themselves. In $57 \%$ of the total sites (21 headspring areas), the roads have deforested margins, and 17 of these have some degree of erosion.
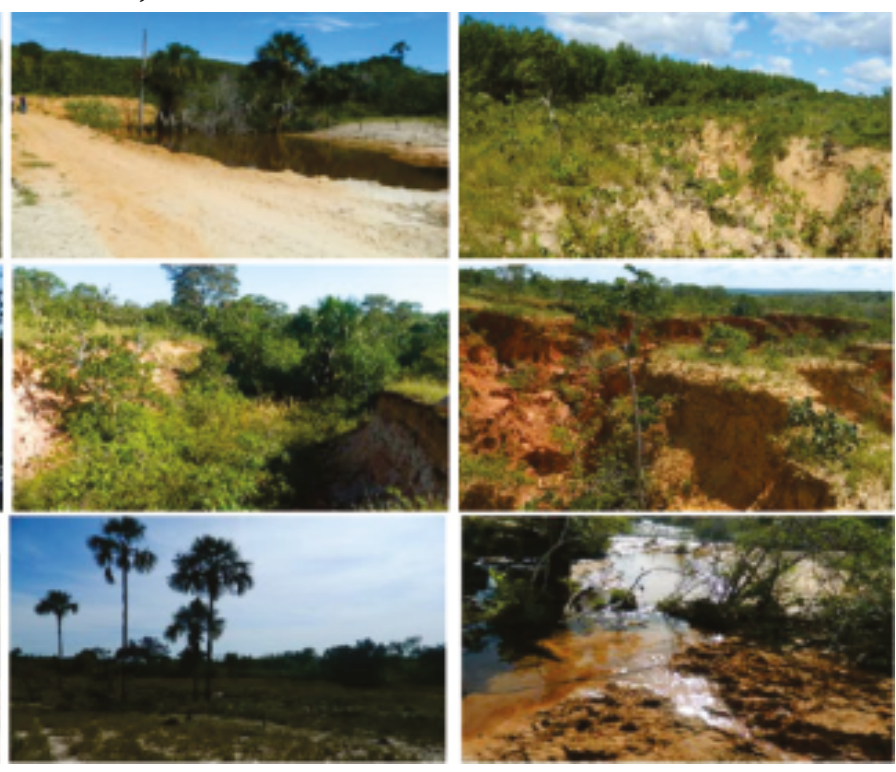

According to Enriquez et al. (2015), the use of unpaved roads promotes soil waterproofing, resulting in reduction of water infiltration rate, and in contrast, favors the increase of surface runoff volume, which are contributing factors for erosion occurrence and sediment production.

Another recurring activity in this region is the eucalyptus monoculture. Thirteen of the observed sites 
(35\%) had planting in APP's, one of which was planted within the headspring area, and in four of these sites, the planting operation was carried out downhill. Those areas where the intervention occurred more significantly, the degradation state and silting condition is more pronounced.

According to Silva et al. (2008), the practice of planting downhill is usually used to facilitate the exploration and removal of wood. However, a study found that one of the areas with the greatest loss of soil per hectare was eucalyptus cultivation planted downhill (Ayer et al., 2015).

In the other 24 evaluated sites (65\%), it verify the presence of the eucalyptus monoculture, however respecting the limits of APP's. Commercial eucalyptus forest planting can provide greater surface runoff and soil erosion when compared to the natural ecosystem. However, as most of these plantations are established in areas that do not have natural vegetation cover, in this context, it starts to promote less surface runoff and, consequently, decreasing the occurrence of water erosion (Maeda and Medrado, 2017).

It was also noted the presence of animals (cattle) in inappropriate places. However, this activity was of low incidence, identifying seven sites (19\%) being used for pasture or as natural drinking fountains, in advanced degradation stage. The headsprings that had intensive trampling were compacted and with little or no water outcrop, in addition some of them presented silting.

The presence of cattle in APP's has a direct consequence in the biodiversity loss, since the animals in these places compact the soil, creating a certain difficulty in the water infiltration, which promotes increase in surface runoff, in addition to being a barrier to seed germination (Silva et al., 2018).

According to Capoane and Santos (2013), the trampling of animals destabilizes the margins of streams and dams, causes silting (silting up) and contamination of them, hindering natural regeneration and soil compaction. It not only compromises the riparian ecosystem, but also the aquatic ecosystem biodiversity.

During the visit, the field team found the construction of a cistern inside the headspring area, from where the water removed was used for animals watering. Its construction was carried out after the suppression of the water outcrops, since the cattle moved freely within the areas of headspring and surroundings. Another improper construction in the footpath area was the water damming in this place, which negatively affected the vegetation, due to the roots drowning, and the water scarcity downstream of the watercourse. In addition to this interference, surroundings areas presented the cultivation of eucalyptus downhill, favoring surface runoff and consequently promoting silting.
According to Cota and Amaral (2018), the construction of dams affects fauna and flora, since there is vegetation suppression and the physical environment changes. Its construction and operation generate these impacts. Erosion occurs due to plant layer deforestation and the soil is exposed to the weather, with the consequence of particles carrying.

The most noticeable degradations found during the visits were erosion, compaction and silting. Erosive processes were the most recurrent, with 23 of the visited sites $(62 \%)$ showing some erosion degree. In 11 of these sites $(30 \%)$, there was laminar erosion, which were identified by the presence of roots in the soil; seven sites (19\%) with erosion in gullet; and five of them (13\%) with groove erosion.

Groove erosions were more frequent on the roads margins, part of them caused by channels builted to remove the surface runoff and carry rainwater to lower slopes and without vegetation cover. However, as no type of barrier was built to contain water in these places, there was an increase in the soil particles carrying to the nearby watercourses, causing their silting.

The erosion process causes problems to the water quality and availability, because of pollution and silting of water bodies, which favors floods occurrence in rainy periods and increased water scarcity in dry periods (Pruski, 2009). In addition, it reduces land productive capacity, which may reduce agricultural exploitation area, and interfere with displacement routes.

The high number of areas with erosive processes caused incidence of watercourses silting. The excess of materials deposited in the water sources and in the gutters of streams/rivers affected 16 of the visited places (43\%), hindering the outcrop of water and its natural course. In addition, six of these places were compacted by the intense cattle traffic.

Silting is a problem, as it alters the normal conditions of the environment, causing its watercourse imbalances and hydrodynamic aspects changes that, over time, facilitate the appearance of sandbanks in the riverbed (Nunes et al., 2014).

According to the conservation status classification of the 37 visited places, only two (6\%) were classified as preserved, $26(70 \%)$ were anthropized and $9(24 \%)$ degraded. Of the 26 points classified as anthropized, 6 were classified as low, 15 as medium and five with a high degree of anthropization.

By the criteria adopted in the present study, the places classified as preserved present dense native vegetation, in which it extends beyond the APP, showing no signs of anthropic activity in the headsprings and surroundings areas, showing itself as a balanced and refuge local ecosystem for fauna. Anthropic activities 
near these sites are roads built without conservation actions, however, because they are outside the APP and in flat and vegetated areas, the risk of erosion caused by surface runoff is low. However, this does not exclude the need to adapt these roads to avoid future damage.
The anthropized places were subclassified according to anthropic activity and existing degradations. Figure 3 shows the existing activities at the sites and the degradation causes.

Figure 3 - Anthropic activities incidence and degradation factors of headsprings (water sources) classified as anthropized in the watershed of the Santa Fé de Minas River, Minas Gerais, Brazil

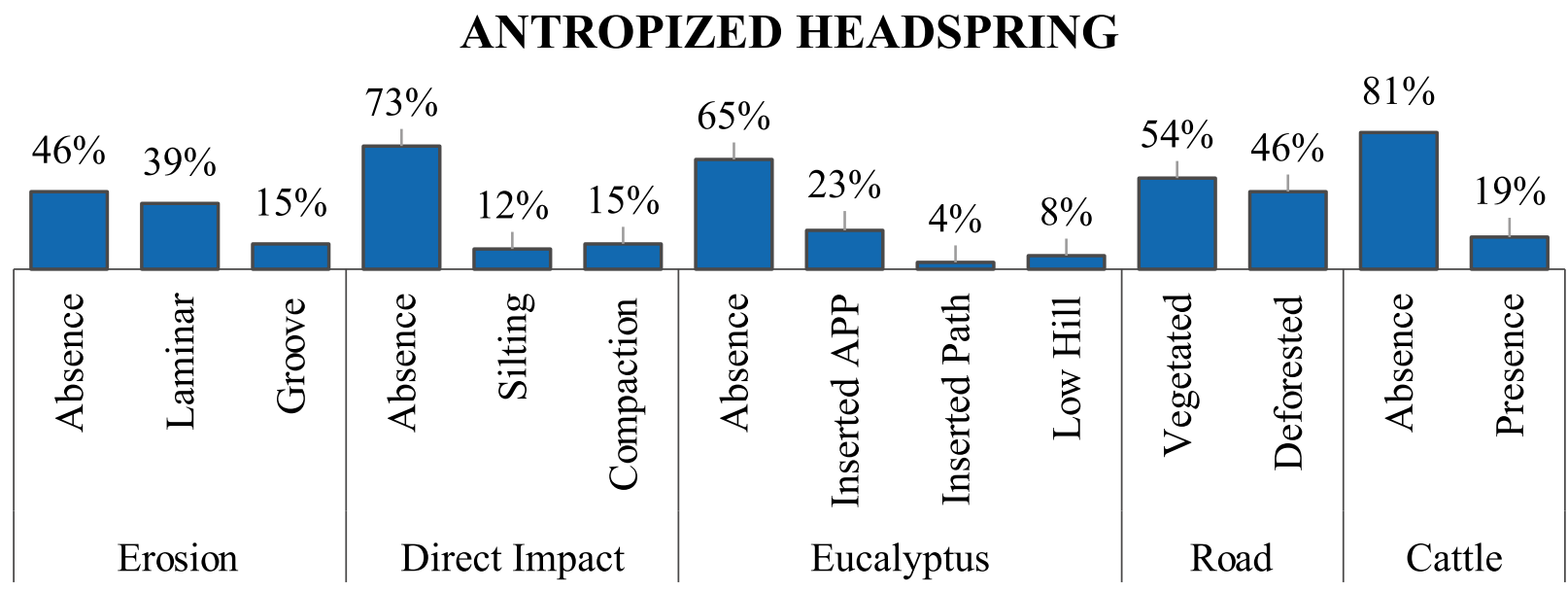

Eucalyptus monoculture was in nine locations, six of which were within the APP. In one of the areas, the planting was carried out at the water outcrop points; in two other places, the eucalyptus was planted downhill, being classified as having a high anthropization degree.

The roads were unpaved in the 26 anthropized places and, in 12 of these places, the roads were more aggravated due to the deforestation of their margins, and with presence of erosion, which were classified as median anthropization degree.

In cattle breeding areas, classified as having an average anthropization degree, the animals had free access to APP's, for watering or to consume native grass, typical of footpath areas.

According to Almeida Filho (2015), impacts on water resources, such as compaction and silting, reduce water quality, decreasing water storage and release capacity, resulting in increased water scarcity and ecosystem changes.

Figure 4 shows the degraded places, indicating the erosion incidence, silting, compaction and the anthropic activities that cause these degradations.

Figure 4 - Degradation incidence and causative agents of degraded headsprings (water sources) in the watershed of the Santa Fé de Minas River, Minas Gerais, Brazil

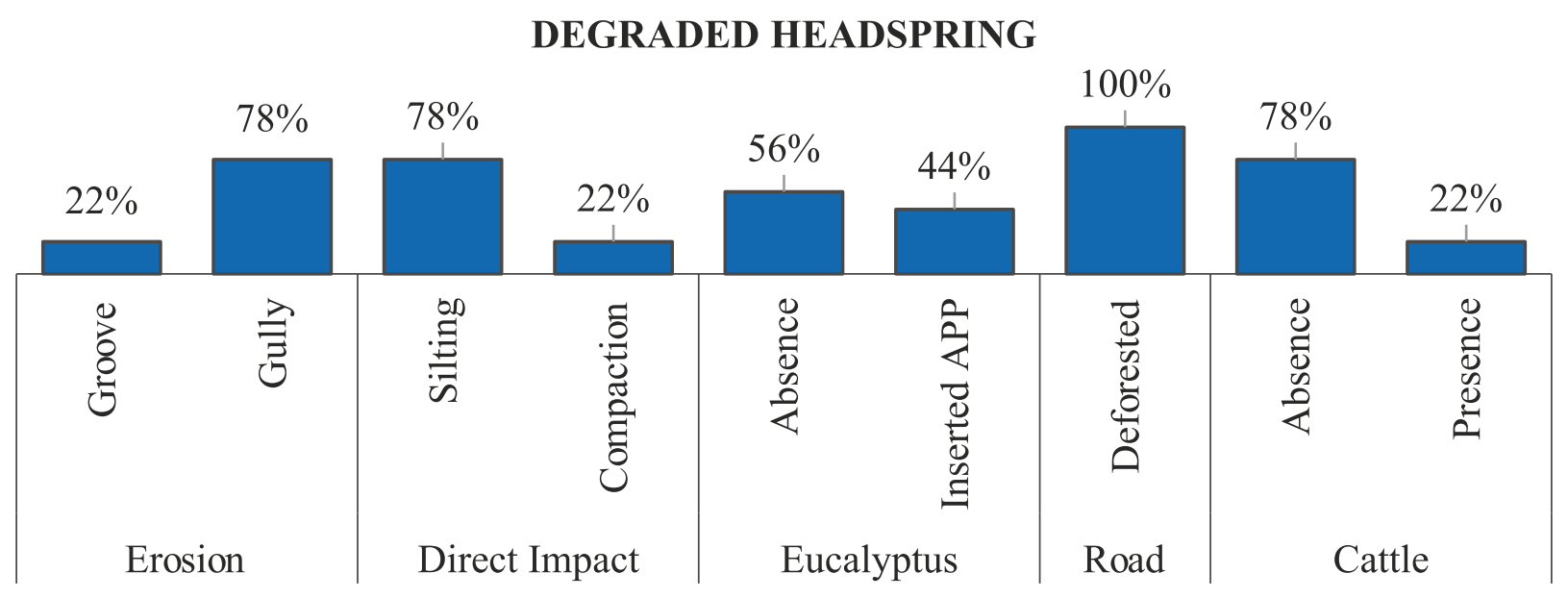


Ferreira, F. L. V. et al.

The most serious situation in areas classified as degraded was the existence of gullies, the most advanced stage of erosion. In some cases, they had large extensions and were dividing the area into two or more parts, making it difficult to access the sites. According to Dotterweich et al. (2012), human activities strongly influence the gullies, which are aggravated due to inadequate soil management practices. This erosion type can cause silting of water bodies and dams, floods, mortality of fauna and flora species, and others (Vieira and Verdum, 2015).

Silting visibly influenced the watercourses located close to or downstream of the areas affected by the erosion processes, and a probable consequence is the total devastation of these places over time.

Four of the degraded places presented the cultivation of eucalyptus in APP's, since, the lack of management is the main reason for degradation. Other anthropic activities that significantly influenced the ecosystem were the presence of cattle and structures built in inappropriate locations.

The soil presented high compaction in places of livestock practices. One of the headsprings was totally transformed into a water reservoir with function of herd watering. These area changes and its surroundings accelerated the degradation process, getting an advanced stage. The unpaved roads near the sites showed to be in a poor conservation state and with advanced degradations, since all of them showed some erosive process and were directly affecting the local system balance.

Figure 5 shows the land use and coverage on the watershed of Santa Fé de Minas River and the classified headsprings. It appears there was an evolution of the agriculture and planted forests areas over the native vegetation areas. The most affected places, degraded and anthropized, are mostly found in the advanced anthropizing areas.

Figure 5 - Land use and coverage and classified headsprings (water sources) in the watershed of Santa Fé de Minas River, Minas Gerais, Brazil

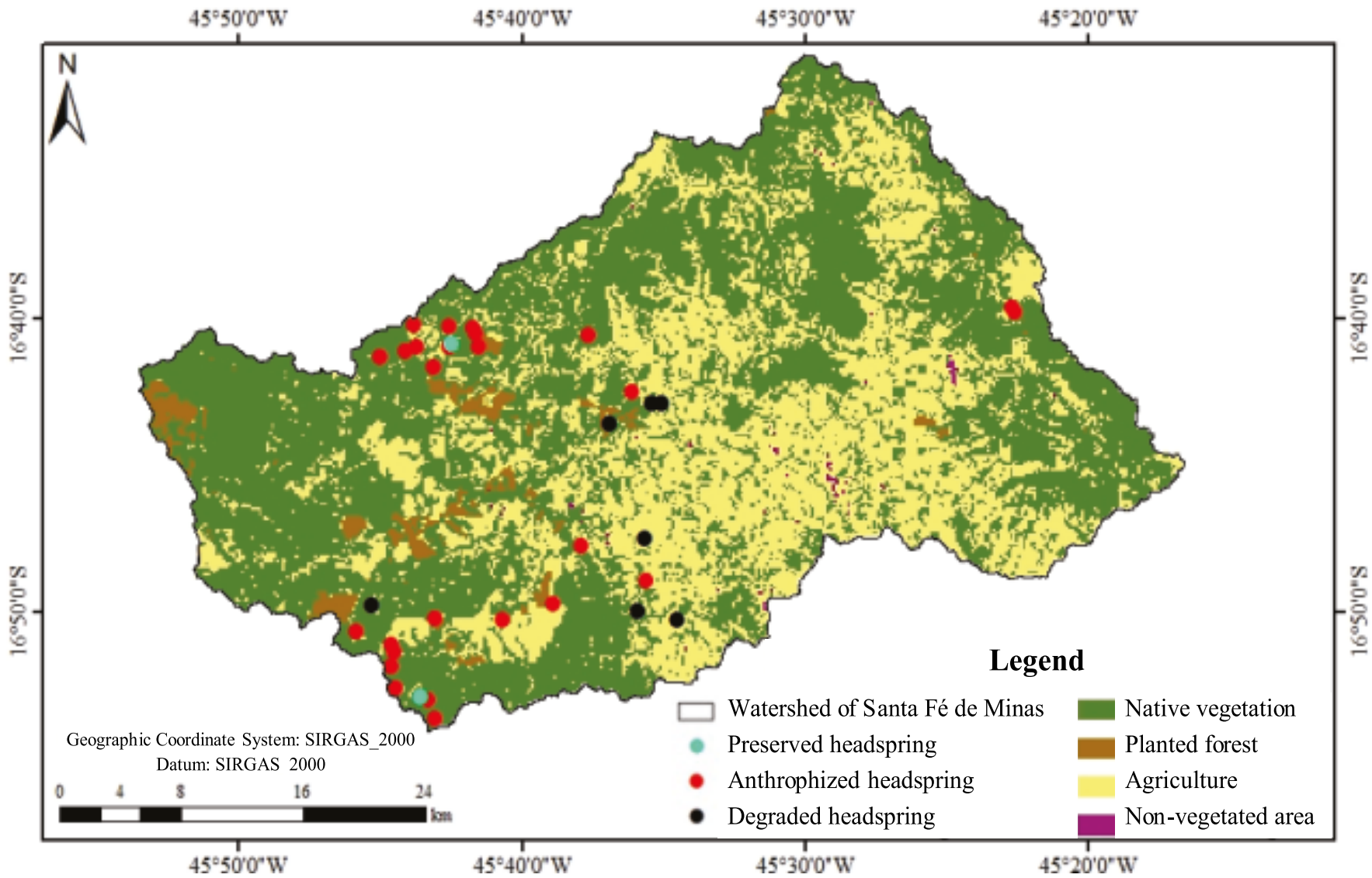

Verifying the current conservation status of the headsprings and surroundings areas, and the identification of the main causative agents, the evaluated areas do not present conservationist practice. It is necessary to implement mitigating acions in these areas to reduce or prevent the degradation progress, since the soil use and water conservation practices provide a balanced ecosystem (Carvalho et al., 2012).
The roads have social and economic importance for the region. Therefore, it proposed that all roads go through an adaptation process. According to Cunha et al. (2013), the containment boxes implantation preserves and control surface runoff and roads sedimentation. These boxes ensure the stabilization of processes arising from the sediments production, with the main objective of rainwater storage, removing water from the roadbed, 
Ferreira, F. L. V. et al.

dissipating energy and facilitating the soil water infiltration. These actions of rural roads adequacy must be part of the municipal organs planning, through conservationist actions that adapt the rainwater use and the erosion control (Taveira and Diniz Jr., 2012).

In relation to pasture areas, it is necessary to build a physical barrier to avoid the cattle trampling in APP's, aiming to control the main agent that causes impacts in the area (Mota et al., 2016). According to Pruski (2009), it recommend periodic reseeding of pasture areas so that it remains with a covering density capable of supporting livestock and guaranteeing good soil protection against erosion.

In monoculture eucalyptus sites, it is advisable to harvest in the appropriate period in order to avoid economic losses. To minimize environmental impacts, it is essential to keep plant remains on the ground during harvest, maintaining the cover and partially replacing lost nutrients (Vital, 2007).

The planting of eucalyptus in areas with groundwater closer to the surface and low rainfall index generates negative impacts on water bodies (Vital, 2007). Thus, planting in these areas should be done in contour lines and with minimal soil preparation in order to reduce environmental changes (Araújo et al., 2009).

According to Silva et al. (2015b), soil loss monitoring due to water erosion must to occur in the forest plantations areas, taking into account the soil loss limits, since it is essential for the adequate and sustainable management of forest plantations.

\section{Conclusion}

The headsprings and surrounding areas on the watershed of the Santa Fé de Minas River are degraded $(24 \%)$ or in degradation process $(70 \%)$.

The anthropic activities that directly or indirectly affect the evaluated areas are unpaved roads, eucalyptus planting and cattle raising, which have been carried out without any type of planning or management strategy. These scenarios generated different types of degradation, such as compaction, different levels of erosion and silting headsprings.

Consevaconist actions such as isolation of headsprings and their surroundings, adequacy of roads and eucalyptus planting areas and maintenance of preservation areas can prevent and control future degradation in the evaluated watershed.

The preservation of the headsprings favors the soil water infiltration, in order to supply the water table, which is extremely important for the Cerrado Biome, since this biome contributes to the hydrological maintenance of different watersheds in the country.

\section{Acknowledgments}

The authors thank the Institute of Agricultural Sciences (ICA / UFMG), the Santa Fé de Minas City Hall and the Public Ministry of Minas Gerais (MPMG) for their support.

\section{References}

Aguiar, S.; Santos, L. de S.; Arêdes, N.; Silva, S. 2016. RedesBioma: Informação e Comunicação para ação sociopolítica em ecorregiões. Ambiente \& Sociedade, 19:3, 231-248. Doi: https://doi. org/10.1590/1809-4422ASOC20140004V1932016.

Albuquerque, R. de A.; Carvalho, F. A. de; Ximenes, T. C. F; Lafayette, K. P. V. 2017. Temporal Evolution of Occupation and Land Use in na Area of Risk Slope's in the City of Jabotão dos Guararapes - Brazil. Eletronic Journal of Geotechnical Engineering, 22:03, 809-818. Doi: http://www.ejge.com/2017/Ppr2017.0066ma.pdf.

Almeida Filho, G. S. de. 2015. Controle de Erosão. Fundações \& Obras Geotécnicas, 5:54, 66-81.

Araújo, L. E. de; Santos M. J. dos; Duarte, S. M.; Oliveira, E. M. 2009. Impactos ambientais em bacias hidrográficas - caso da bacia do Rio Paraíba. TECNO-LÓGICA, 13:2, 109-115. Doi: http://dx.doi. org/10.17058/tecnolog.v13i2.855.

Ayer, J. E. B.; Olivetti, D.; Mincato, R. L.; Silva, M. L. N. 2015. Erosão hídrica em Latossolos Vermelhos distróficos. Pesquisa Agropecuária Tropical, 45:2, 180-191. Doi: https://doi.org/10.1590/1983$40632015 v 4531197$.
Brasil. 2012. Lei no 12.651, de 25 de maio de 2012. Disponível em: < http://www.planalto.gov.br/ccivil_03/_Ato2011-2014/2012/Lei/ L12651.htm >. Acesso em: 05 dez 2019.

Calaça, A.; Silva, D. A.; Oliveira, S. R.; Melo, F. R. de. 2018. Mammals recorded in isolated remnants of Atlantic Forest in southern Goiás, Brazil. Biota Neotropica, 19:1. Doi: http://dx.doi.org/10.1590/16760611-bn-2018-0575.

CONAMA - Conselho Nacional do Meio Ambiente. 2002. Resolução no 3003, de 20 de março de 2002. Disponível em: < http://www2.mma.gov. br/port/conama/legiabre.cfm?codlegi=299 > . Acesso em: 05 dez 2019.

Capoane, V.; Santos, D. R. dos. 2013. Usos antrópicos em áreas de preservação permanente: estudo de caso em um assentamento de reforma agrária. Revista Extensão Rural, 20:7-23. Doi: https:// periodicos.ufsm.br/extensaorural/article/view/8568.

Carvalho, A. P. V.; Brumatti, D. V.; Dias, H. C. T. 2012. Importância do manejo da bacia hidrográfica e da determinação de processos hidrológicos. Revista Brasileira de Agropecuária Sustentável (RBAS), 2:2, 148-156. Doi: https://doi.org/10.21206/rbas.v2i2.177. 
Ferreira, F. L. V. et al.

Cota, L. Da S.; Amaral, D. R. B. 2018. A importância e os impactos oriundos da implantação de barragens de terra-estudo de caso: barragem Norida Vieira de Lima. Humanidades \& Tecnologia Em Revista, 12, 66-83. Doi: https://www.finom.edu.br/assets/site/paginas/files/ downloads/20180625150641.pdf\#page $=66$.

Cunha, M. C. Da; Thomaz, E. L.; Vestena, L. R. 2013. Erosion control measures of rural roads in the Rio das Pedras basin, Guarapuava Paraná (Brazil). Sociedade \& Natureza, 25:1, 107-118. Doi: https:// doi.org/10.1590/S1982-45132013000100009.

Dotterweich, M. 2012. High resolution gully erosion and sedimentation processes, and land use changes since the Bronze Age and future trajectories in the Kazimierz Dolny area (NałęczówPlateau, SEPoland). Catena, 95:1, 50-62. Doi: https://doi.org/10.1016/j. catena.2012.03.001.

Enriquez, G. A; Silva, D. P. Da; Pruski, F. F; Griebeler, N. P.; Cecon, P. R. 2015. Erodibilidade e tensão crítica de cisalhamento no canal de drenagem de estrada rural não pavimentada. Revista Brasileira de Engenharia Agrícola e Ambiental, 19:2, 160-165. Doi: http://dx.doi. org/10.1590/1807-1929/agriambi.v19n2p160165.

Fernandes, M. M.; Ceddia, M. B.; Francelino, M. R.; Fernandes, M. R. de M. 2015. Diagnóstico ambiental da faixa ciliar e qualidade de água de duas microbacias utilizadas para abastecimento humano. Irriga, 20:1, 128138. Doi: https://doi.org/10.15809/irriga.2015v20n1p128.

Ferreira, F. L. V.; Rodrigues, L. N.; Almeida, L. T. de; Teixeira, D. B. de S. 2020. Trend in hydrological series and changes in land use and land cover in the Guanhães, Minas Gerais river basin. Brazilian Journal of Animal and Environmental Research, 3:2, 447-459. Doi: https://doi. org/10.34188/bjaerv3n2-004.

Ferreira, R. Q. de S.; Batista, E. C.; Souza, P. A.; Souza, P. B.; Santos, A. F. dos. 2015. Diagnóstico ambiental do córrego Mutuca, Gurupi - TO. Revista Verde de Agroecologia e Desenvolvimento Sustentável, 10:4, 08-12. Doi: http://dx.doi.org/10.18378/rvads.v10i4.3146.

Galatto, S. L.; Alexandre, N, Z.; Pereira, J. L.; Patrício, T. B.; Vassiliou, M.; Fernandes, A. N.; Frassetto, J.; Valvassori, M. L. 2011. Diagnóstico ambiental de nascentes no município de Criciúma, Santa Catarina. Revista de Ciências Ambientais, 5:1, 39-56. Doi: http://dx.doi. org/10.18316/136.

Garcia, Y. M; Campos, S.; Spadotto, A. J.; Campos, M. de; Silveira, G. R. P. de. 2015. Caracterização de conflitos de uso do solo em APPs na bacia hidrográfica do córrego Barra Seca (Pederneiras/SP). Revista Energia na Agricultura, 30:1, 68-73. Doi: https://doi.org/10.17224/ EnergAgric.2015v30n1p68-73.

IBGE - Instituto Brasileiro de Geografia e Estatística. 2010. Informações completas, 2010. Disponível em: < http://cidades.ibge.gov.br>. Acesso em: 05 jun 2019.

IGAM - Instituto Mineiro de Gestão das Águas. 2006. Plano diretor de recursos hídricos da bacia hidrográfica do Rio Paracatu: Resumo Executivo. Belo Horizonte: Instituto Mineiro de Gestão das Águas, 2006. 385 p. Doi: http://www.repositorioigam.meioambiente.mg.gov. br/handle/123456789/677.

Köppen, W. 1936. Das geographische system der klimate. In: Handbuch der klimatologie, Köppen, W.; Geiger, R. (Eds.), GebruderBorntrager, Berlin, 1, 1-44, part C. Doi: http://koeppen-geiger.vu-wien.ac.at/pdf/ Koppen_1936.pdf.

Maeda, S.; Medrado, M. J. S. 2017. Plantações florestais comerciais e o solo. In: OLIVEIRA, Y. M. M. De; OLIVEIRA, E. B. de (ed.). Plantações florestais: geração de benefícios com baixo impacto ambiental. Brasília, DF: Embrapa. 2, 21-30. Doi: http://acr.org.br/download/biblioteca/01. pdf.
Mendes, T. A.; Mariano, J. V.; Marques, P. H. G.; Santos, L. De P. S. 2016. Diagnóstico ambiental da área de preservação permanente da nascente do córrego Almeida utilizando ferramenta de geoprocessamento (Aparecida de Goiânia - GO). Ciência e Natura, 38:3. Doi: http://dx.doi. org/10.5902/2179460X22867.

Morais, R. C. De S.; Sales, M. C. L. 2017. Estimativa do potencial natural de erosão dos solos da bacia hidrográfica do Alto Gurguéia, Piauí - Brasil, com uso de Sistema de Informação Geográfica. Caderno de Geografia, 27:1, 84-105. Doi: https://doi.org/10.5752/p.23182962.2017v27nesp1p84.

Mota, A. R.; Camargo, M. O.; Souza, P. A. de; Souza, P. B De.; Santos, A. F. dos. 2016. Diagnóstico ambiental no córrego Bacaba, Talismã - TO. Revista Verde de Agroecologia e Desenvolvimento Sustentável, 11:1, 14-19. Doi: http://dx.doi.org/10.18378/rvads.v11i1.3893.

Moura, V.; Silva, J. P. C.; Rosell, E. C. F; Alves, W. W. de A. 2017. Análise multitemporal do uso e ocupação do solo em Áreas de Preservação Permanente (APP) na bacia do rio Piranha, São Miguel do Guaporé, Rondônia (RO), Brasil. Revista Geográfica Venezolana, 58:2, 414-429. Doi: https://www.redalyc.org/pdf/3477/347753793010.pdf.

Nunes, H. K. B.; Gomes, M. L.; Paula, J. E. A. 2014. Assoreamento e formação de bancos de areia no leito do rio Parnaíba, na zona urbana de Teresina - Piauí. Revista Geonorte, 10:1, 156-160. Doi: https:// www.periodicos.ufam.edu.br/index.php/revista-geonorte/article/ view/1537/1419.

Palivoda, A. P; Povaluk, M. 2015. Avaliação do estado de conservação de nascentes localizadas em áreas rurais do município de Itaiópolis, SC. Saúde e Meio Ambiente, 4:1, 17-31. Doi: http://www.periodicos. unc.br/index.php/sma/article/view/609.

Pinto, L.V. A. 2003. Caracterização física da sub-bacia do Ribeirão Santa Cruz, Lavras, MG, e propostas de recuperação de suas nascentes.165. Dissertação (Mestrado em Engenharia Florestal) - Universidade Federal de Lavras. Doi: http://repositorio.ufla.br/jspui/handle/1/28095.

Pruski, F. F. 2009. Prejuízos decorrentes da erosão hídrica e tolerância de perdas de solo. In: Pruski, F. F. (ed.). Conservação do solo e água: práticas mecânicas para o controle da erosão hídrica. 2. ed. Viçosa: Ed.: UFV. 1, 13-23.

Silva, A. J.; Monteiro, M. S. L.; Silva, M. V. 2015a. Contrapontos da consolidação do agronegócio no cerrado brasileiro. Sociedade e Território, 27:3, 95-114. Doi: https://periodicos.ufrn.br/sociedadeeterritorio/ article/view/7302.

Silva Junior, C. H. L.; Freire, A. T. G.; Mendes, J. J. 2015. Lógica Fuzzy e processo analítico hierárquico - AHP na avaliação da qualidade ambiental de nascentes. Revista Eletrônica em Gestão, Educação e Tecnologia Ambiental, 19:2, 292-303. Doi: 10.5902/2236117016849.

Silva, J. De C.; Castro, V. R. de; Xavier, B. 2008. A. Cartilha do Fazendeiro Florestal. 2. ed. Viçosa: Ednilton Lopes Fialho, 44. Doi: http://www. ciflorestas.com.br/arquivos/doc_cartilha_2008_27219.pdf.

Silva. J. L.; Tonello, K. C.; Valente, R. A.; Mingote, R. 2016. Diagnóstico ambiental como subsídio à restauração floresta e manutenção hidrológica da bacia do ribeirão dos Pinheirinhos, Brotas - SP. Irriga, 21:1, 1-13. Doi: https://doi.org/10.15809/irriga.2016v21n1p1-13.

Silva, M. L. N.; Cândico, B. M.; Curi, N.; Batista, P. V. G. 2015b. Erosão hídrica em talhões e estradas florestas: monitoramento, causas e controle. Série técnica IPEF, 23:44. Doi: https://www.researchgate. net/publication/290434501_Erosao_hidrica_em_talhoes_e_estradas florestais_monitoramento_causas_e_controle. 
Ferreira, F. L. V. et al.

Silva, T. G. N.; Gama, R. Da C.; Teixeira, L. G.; Santos, G. R. Dos; Sousa, R. M De; Souza, P. B. de. 2018. Diagnóstico ambiental de uma área de proteção permanente (app), Formoso do Araguaia - TO. Revista da Universidade Vale do Rio Verde, 16:2. Doi: http://dx.doi.org/10.5892/ ruvrd.v16i2.4619.

Taveira, L. S.; Diniz Jr, G. M. 2012. O impacto ambiental causado pela rede viária. In: Hammes, V. S. (ed.). Julgar: percepção do impacto ambiental. 3 ed. Brasília, DF: Embrapa, 251-254.
Vieira, C. L.; Verdum, R. 2015. Arenização e erosão hídrica no sudoeste do Rio Grande do Sul: análise dos agentes condicionantes e considerações básicas para intervenções mecânico-vegetativas. Revista de Geografia, 32:1. Doi: https://periodicos.ufpe.br/revistas/revistageografia/article/ view/229134/23533.

Vital, M. H. F. 2007. Impacto Ambiental de Florestas de Eucalipto. Revista do BNDES, 14:28, 235-276. Doi: https://web.bndes.gov.br/ bib/jspui/handle/1408/12554. 